\title{
Pericarp ontogeny and histochemistry of the exotesta and pseudocaruncle of Euphorbia milii (Euphorbiaceae)
}

\author{
Ontogênese do pericarpo e histoquímica da exotesta e pseudocarúncula \\ de Euphorbia milii (Euphorbiaceae)
}

Diego Demarco $^{1,3}$ \& Sandra Maria Carmello-Guerreiro ${ }^{2}$

\begin{abstract}
Several types of fruit occur in Euphorbiaceae, notably the explosively dehiscent dry fruit, and different seed-coat anatomies with taxonomic importance. This paper aims to describe the pericarp ontogeny and structure in Euphorbia milii Desmoul., and evaluate the presence of the secretory exotesta and caruncle. The fruit is a schizocarp, whose the pericarp development begins with a periclinal division of the inner epidermal cells. The derived cells divide, forming about four layers of obliquely elongated cells. Then, the adjacent parenchyma cells elongate, giving rise to a palisade layer and finally, the cells between this layer and the vascular strands undergo mitosis, originating about four layers of elongated cells perpendicularly to the inner oblique cells. These three zones lignify, while the region between the vascular strands and the exocarp, where idioblasts, hypodermis and laticifers are present do not show significant changes. Before the dehiscence, a lysis of cells of the septa and the desiccation of the fruit occur, which causes contraction of the non-lignified tissues and tension between the lignified zones, promoting rupture of each mericarp from central columella and on the dorsal strand, ejecting the seeds. The seeds have pseudocaruncle and the exotesta secretes mucilage, facilitating their imbibition.
\end{abstract}

Key words: anatomy, crown-of-thorns, development, fruit, seed.

\section{Resumo}

Diversos tipos de frutos ocorrem em Euphorbiaceae, destacando-se os secos de deiscência explosiva e sementes com envoltórios de diferentes estruturas e importância taxonômica. O objetivo deste trabalho foi descrever a ontogênese do pericarpo de Euphorbia milii Desmoul. e avaliar, em termos histoquímicos, a exotesta secretora e a presença de carúncula. $\mathrm{O}$ fruto é um esquizocarpo, cujo desenvolvimento do pericarpo se inicia pela divisão periclinal das células da epiderme interna. As derivadas dividem-se, formando cerca de quatro camadas de células alongadas obliquamente. Em seguida, as células parenquimáticas adjacentes alongam-se, formando uma camada em paliçada e então, as células entre a camada em paliçada e os feixes vasculares dividem-se, originando cerca de quatro camadas de células alongadas perpendicularmente às células oblíquas internas. Estas três zonas lignificamse, enquanto a região entre os feixes vasculares e o exocarpo, que possui idioblastos, hipoderme e laticíferos, não apresenta mudanças significativas. Antes da deiscência ocorre lise das células dos septos e dessecamento do fruto, o qual gera contração dos tecidos não lignificados e tensão entre as zonas lignificadas, rompendo os mericarpos em relação à columela central e na região do feixe dorsal, lançando as sementes. As sementes possuem pseudocarúncula e a exotesta secreta mucilagem, facilitando sua embebição.

Palavras-chave: anatomia, coroa-de-cristo, desenvolvimento, fruto, semente.

\section{Introduction}

Euphorbiaceae is known by its explosively dehiscent dry fruits, described as schizocarps with three elastically dehiscent mericarps (cocci) and persistent columella (Webster 1994). While this type of fruit is prevalent in Euphorbiaceae, fleshy and indehiscent fruits are also found in the different subfamilies (Webster 1994; Esser 2003).

There are many anatomical studies on the Euphorbiaceae seeds, but few studies on the structure

\footnotetext{
${ }^{1}$ Universidade de São Paulo, Instituto de Biociências, Depto. Botânica, C.P 11461, 05508-090, São Paulo, SP, Brasil.

${ }^{2}$ Universidade Estadual de Campinas, Instituto de Biologia, Depto. Biologia Vegetal, C.P. 6109, 13083-970, Campinas, SP, Brasil.

${ }^{3}$ Autor para correspondência: diegodemarco@usp.br
} 
of the fruits have been carried out (Sablon 1884; Lavialle \& Delacroix 1922 a,b,c; Oliveira \& Oliveira 2009), and only Lavialle \& Delacroix (1922a) have studied the ontogeny of the fruits in Euphorbia L. species. The researches are usually restricted to the analysis of the seeds, of which size, shape, ornamentation, seed coat anatomy, development of the endosperm and configuration of the embryo are taxonomically important characteristics, specially to the generic and specific levels (Jordan \& Hayden 1992; Simon et al. 1992; Webster 1994).

Secretory structures are rare in Euphorbiaceae fruits and little to no emphasis is given to them in the few anatomic studies already made. The data contained in literature basically refer to the presence of the caruncle (elaiosome), secretory exotesta and sarcotesta in some few species (Jordan \& Hayden 1992; Webster 1994; Lisci et al. 1996; Tokuoka \& Tobe 2002), and there are few studies reporting the presence of laticifers and secretory idioblasts at the pericarp (Lavialle \& Delacroix 1922a,b,c; Jimenez \& Morales 1978; Oliveira \& Oliveira 2009).

The presence of a caruncle is a common characteristic in Euphorbiaceae (Webster 1994). This structure develops from the outer integument, at the micropyle region, and has a well-defined ecological function of secondary dispersion by ants (elaiosome), besides acting in the seed dehydration, hydration, dormancy, and water storage (Webster 1994; Lisci et al. 1996). Although the presence of a mucilaginous exotesta has been reported for many species of Euphorbia (including Chamaesyce; Carlquist 1966; Jordan et al. 1985; Jordan \& Hayden 1992), those reports are mostly based on the secretion aspect, and neither the chemical composition of the secretion nor the characteristics of the secreting cells were observed.

The ovule and the seed of Euphorbia milii have already been described by Bor \& Bouman (1974) and, although they have described the exotesta as mucilage-secreting due to the viscous aspect and the white coloration of the secretion which surrounds the seed, no tests were carried out to determine its real composition.

In the Euphorbiaceae species with dry fruits, the dispersion usually occurs by autochory or diplochory, and zoochory in some cases (Webster 1994; Esser 2003; Narbona et al. 2005). Diplochory is very common in Euphorbiaceae and is known as "euphorbia-like" dispersion, even though not all species in the genus have its secondary dispersion done by ants (Berg 1975; Webster 1994; Esser 2003).

The present study aimed to describe the pericarp ontogeny of Euphorbia milii Desmoul., including its secretory structures, and evaluate structurally and histochemically the data presented by Bor \& Bouman (1974) for the secretory exotesta and for the occurrence of the caruncle in this species. This data can assist in understanding the process which leads to seed dispersion through explosive dehiscence, the possibility of secondary dispersion by ants and the function of the exotesta secretion for the seed germination.

\section{Materials and Methods}

Cyathia and fruits of five individuals of Euphorbia milii Desmoul. were collected in the city of Campinas (22 $54^{\prime} 20^{\prime}$ ' $\mathrm{S} / 47^{\circ} 03^{\prime} 39^{\prime}$ ' $\mathrm{W}$ ) and fixed in FAA (formalin, acetic acid, alcohol 50\%) for $24 \mathrm{~h}$ (Johansen 1940) or NBF (neutral buffered formalin) in $0.1 \mathrm{M} \mathrm{pH} 7.0$ sodium phosphate buffer (Lillie 1965) for $48 \mathrm{~h}$ and preserved in $70 \%$ ethyl alcohol. Voucher specimens of the analyzed individuals were deposited in the UEC Herbarium (05.X.2001, D. Demarco 2; 03.V.2004, D. Demarco $12,13)$.

Fruits in early development (about $2.5 \mathrm{~mm}$ high and $3.0 \mathrm{~mm}$ wide) were isolated, dehydrated in a butyl series (tertiary butyl alcohol; Johansen 1940), included in Paraplast ${ }^{\circledR}$, and $8 \mu \mathrm{m}$ thick sections were made using a Microm HM340E rotary microtome, stained with astra blue and safranin (Gerlach 1984). The slides were mounted in synthetic resin. The other fruits were dehydrated in an ethanol series, included in hydroxyethylmetacrylate (Gerrits 1991), sectioned at a thickness of $25 \mu \mathrm{m}$ and stained with Toluidine Blue $0.05 \%$ (O'Brien et al. 1964) in acetate buffer $\mathrm{pH} 4.7$.

For the micromorphological analysis, seeds fixed in FAA were dehydrated in an ethanol series, critical point dried, and mounted and metalized with gold. The observations and the images obtained were made using a (MEV) Jeol JSM 5800 LV scanning electron microscope to $10 \mathrm{kV}$ with a builtin digital camera.

For the histochemical analysis of the exotesta secretion and occurrence of caruncle, mature seeds fixed in FAA (for the tests with hydrophilic substances) and NBF (for the tests with lipophilic 
substances) were used, included in plastic resin. The performed tests were: ruthenium red (Gregory \& Baas 1989) and alcian blue (C.I. 74240; Pearse 1985) for acidic mucilage, tannic acid and ferric chloride for mucilage (Pizzolato 1977), Periodic-Acid-Schiff's reagent; pararosaniline (C.I. 42500) for carbohydrates (McManus 1948), Sudan black B (C.I. 26150) and Sudan IV (C.I. 26105) for total lipids (Pearse 1985), Nile blue (C.I. 51180) for acidic and neutral lipids (Cain 1947), copper acetate and rubeanic acid for fatty acids (Ganter \& Jollés 1969, 1970), ferric chloride (Johansen 1940) and potassium dichromate (Gabe 1968) for phenolic compounds.

Seeds were kept for $48 \mathrm{~h}$ in a solution composed of methanol, chloroform, water and hydrochloric acid (High 1984) for test control for lipophilic substances. After this period, the material was fixed in NBF and received the same treatment of the other pieces. The controls of the tests for hydrophilic substances were made according to the respective technique.

The photomicrographs were obtained using an Olympus BX51 microscope and a Kodak ProImage ISO 100 film. The scales of the figures were obtained using a micrometer blade photographed in the same optical conditions as the other illustrations. The measurements of the fruits were made using a digital caliper to an accuracy of $0.01 \mathrm{~mm}$.

\section{Results}

\section{Fruit}

The Euphorbia milii fruit is a dry, trilobate schizocarp, which is 4 to $5 \mathrm{~mm}$ in length and 4.5 to $5 \mathrm{~mm}$ in width, glabrous, presents three mericarps (Fig. 1a-b) and is elevated above the cyathium involucre due to the growth of the peduncle (Fig. 1c-d). As the pericarp desiccates, its surface becomes irregular and gets a striated appearance (Fig. 1a-b). The immature fruit, with the individualized mericarps, is red, and at maturity, after the desiccation which precedes the dehiscence, becomes brown. The constant dehydration of the fruit causes the mericarps to detach in relation to the central columella, and they open at the locule, throwing their halves (valves) and then the seed (Fig. 1e) far away from the mother plant. Only the central columella remains above the peduncle (Fig. 1d). Thus, the fruit initially presents the individualization of the mericarps, and then septifragal and loculicidal dehiscences, releasing the seeds (Fig. 1e-f).

\section{Ontogeny of the pericarp}

The pistillate flower is consisted only of the three-carpel syncarpous gynoecium, containing one ovule per locule (Fig. 2a). The ovary wall consists of unistratified outer epidermis with square cells, in transversal section, and a voluminous nucleus; ground tissue consisted by six to ten parenchymatous cell layers (Fig. 2b), where vascular strands, idioblasts and laticifers are scattered; and unistratified inner epidermis with voluminous nucleus, in center position (Fig. 2b).

The fruit begins its development while still inside the cyathium involucre. The endocarp is periclinally divided forming two layers of cells (Fig. $2 \mathrm{c})$ and, together with those modifications, parenchymatous cells are divided and elongated, forming the mesocarp.

At the next stage, the modifications still happen only at the mesocarp and endocarp of each mericarp, and the exocarp does not show any other modification, except for anticlinal divisions that follow the fruit growth. At the mesocarp, the divisions in different planes (Fig. 2d) add volume to the fruit, and the increase of the laticifers (Fig. $2 c)$ and of the vascularization is observed. The final mesocarp layer, adjacent to the bistratified endocarp, begins its elongation radially, presenting a voluminous nucleus at this stage. The endocarp cells start its oblique elongation, $45^{\circ}$ tilted in relation to the biggest axis of the fruit (Fig. 2d).

At a third stage, the three mericarps are well defined and the pericarp presents an unistratified exocarp, whose cells present periclinal convex external wall and dense aspect cytoplasm (Fig. 2e). The mesocarp presents the laticifers and vascular strands at their biggest size, very evident at this time, the dorsal strand and the two ventral strands (Fig. 3a-b, d).

The final mesocarp layer reaches its maximum radial elongation, forming a palisade layer (Fig. 2e, 3a,c-d, 4a). Adjacent to this layer, two to four mesocarp layers are obliquely elongated, $45^{\circ}$ tilted in relation to the biggest axis of the fruit and perpendicular to the obliquely elongated endocarp cells. The bistratified endocarp is once again divided and the resultant cells also elongate obliquely, forming three to four cell layers (Fig. 2e, 3a, 3c, 4a). At this stage, we can observe the interruption of the mesocarp with oblique and radially elongated cells and of the oblique endocarp, near the dorsal and ventral vascular strands (Fig. 3a-d, 4b), forming the future lines of dehiscence of the fruit. 


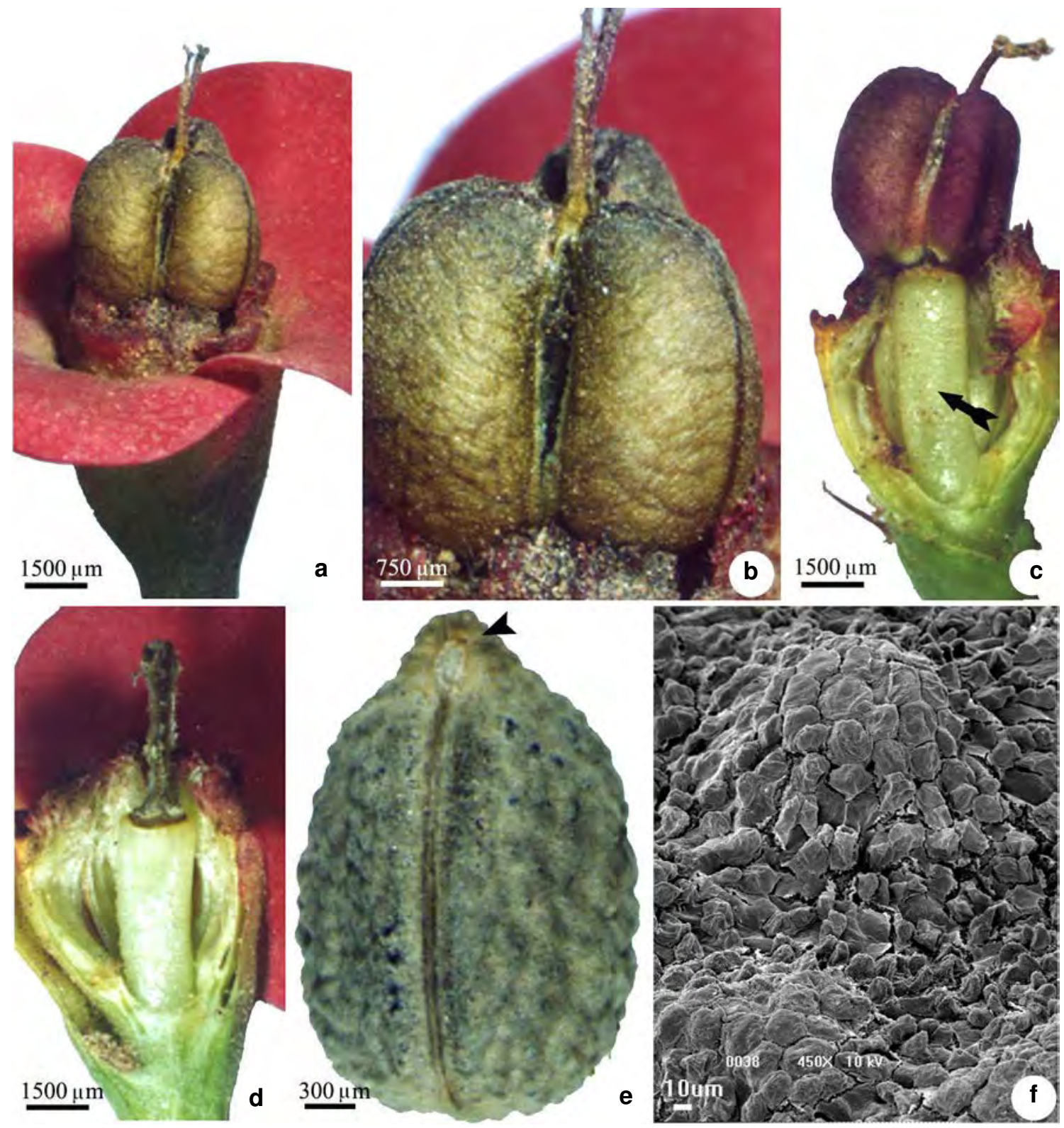

Figure 1 - Fruits and seeds of Euphorbia milii Desmoul. - a. general view of dry fruit; b. detail of figure a; c. mature fruit before desiccation. Note the developed peduncle, elevating the fruit above the cyathium involucre (arrow); d. central columella on the top of the peduncle after fruit dehiscence; e. general view of mature seed (arrow head = pseudocaruncle); f. surface of the mature seed observed in SEM.

After this stage, the cell divisions cease, and the oblique cells of the mesocarp, of the palisade layer and the endocarp oblique cells reach their maximum elongation and become lignified (Figs. 3a-d, 4a-d).

The pericarp of a mature fruit is consisted of: 1) unistratified exocarp; 2) mesocarp, parenchymatous on the outside, where the vascular strands and the laticifers are scattered; 3) lignified inner section of the mesocarp, composed of three to four layers of cells, elongated $45^{\circ}$ in relation to the biggest axis of the fruit; 4) unistratified, lignified, palisade layer, as the innermost layer of the mesocarp; 5) endocarp with three to four elongated cells layers, perpendicular to the oblique mesocarp cells, also lignified, and a nonlignified layer coating the locule (Fig. 4c). 

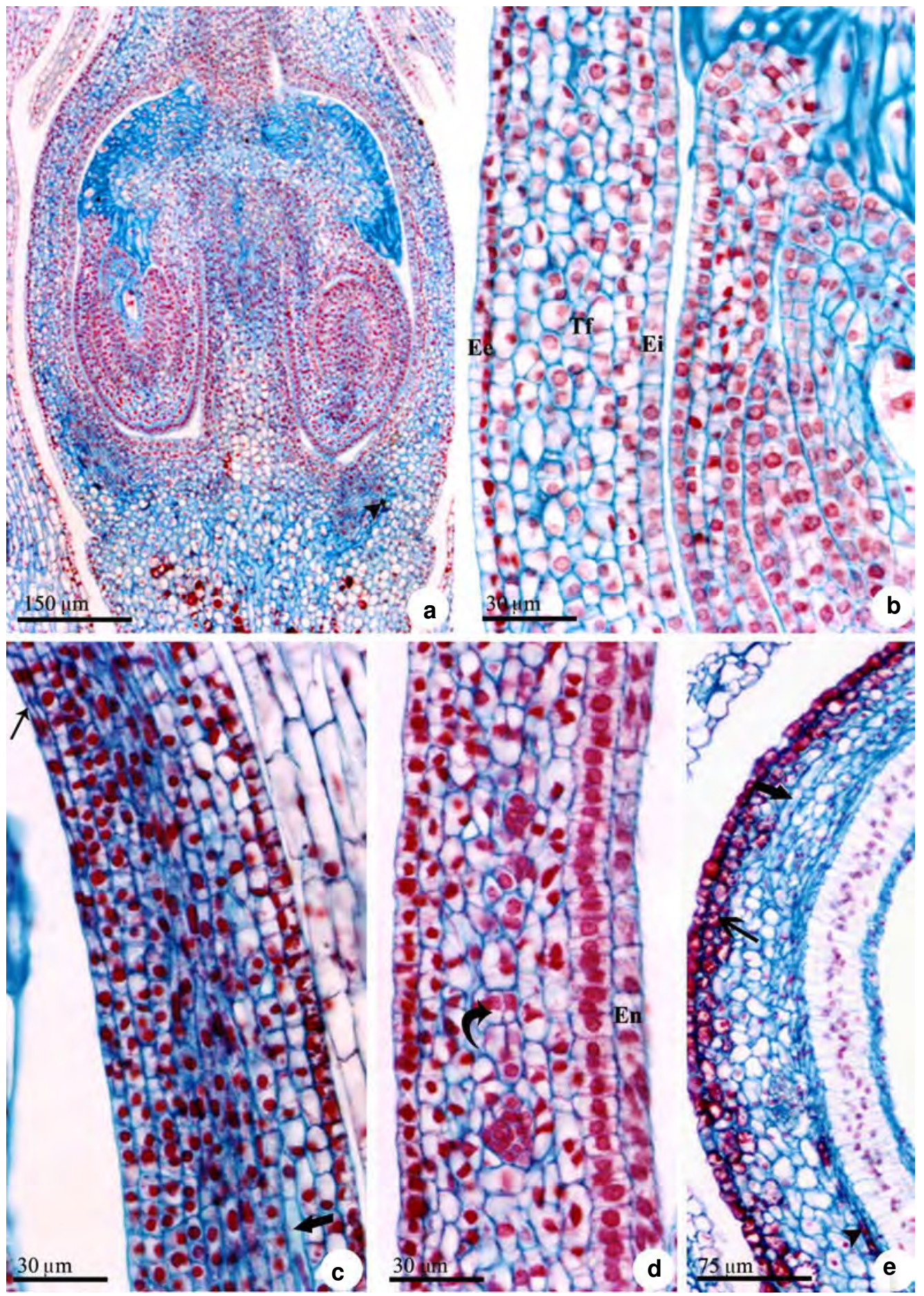

Figure 2 - Flower and fruit of Euphorbia milii Desmoul. Longitudinal sections - a. general view of the ovary (arrow head = idioblast $)$; . detail of the figure a showing the ovary wall $(\mathrm{Ee}=$ outer epidermis; $\mathrm{Ei}=$ inner epidermis; $\mathrm{Tf}=$ ground tissue); c. beginning of the bistratified endocarp development by periclinal division of the inner epidermis (narrow arrow) (wide arrow = laticifer); $d$. radial elongation of the parenchyma cells adjacent to endocarp (En). Note the division of the mesocarp cells (curve arrow); e. general view of the pericarp with the three distinct zones. Note the palisade layer. (narrow arrow $=$ hypodermis; wide arrow $=$ laticifer; arrow head $=$ idioblast $)$. 


\section{Ripening and dehiscence}

At the beginning of the fruit ripening process, a degeneration of parenchymatous cells of the mesocarp occurs at the basal (Fig. 3a) and apical (Fig. 3c) thirds of the fruit, but at the middle third, a compression of the parenchymatous cells occur, and the mericarps remain joined together and to the central columella by a layer of very thin collapsed cells and by the vascular strands (Fig. 3b).

Posteriorly, with the increase in the fruit volume and by an autolysis process, the parenchymatous cells of the mesocarp break at the septal region, dividing the fruit in three mericarps (Fig. 1a-c). At this stage, the mericarps, unbroken and preserving the seed, are tied to the central columella only by the apical and basal thirds. This is the beginning of the septifragal dehiscence.

At this stage, each mericarp begins to lose water, which leads to the contraction of the parenchymatous cells of the mesocarp outer portion (Fig. 4d) and changes the fruit coloration from red to brown. This desiccation increases the tension among the lignified layers of oblique cells, the endocarp and the mesocarp, and the palisade layer, exerting forces in different directions, as they are elongated to different directions. The tension keeps rising until the mericarps are completely released from the central columella, completing the septifragal dehiscence. Next, the pericarp of each mericarp breaks at the two weakest parts: along the dorsal strand (loculicidal dehiscence, Fig. 3d) and next to the ventral strands, where the lignified layers are abruptly interrupted (Fig. 4b). The rupture at the locule occurs in an explosive way, and throws the seeds together with the twisted halves of each mericarp far away from the mother plant, leaving behind the central columella over the peduncle (Fig. 1d), sometimes with the styles and stigmas.

The fruit, thus, presents at first a septicidal and a partially septifragal separation, originating the three mericarps, and then, at a second stage, the septicidal dehiscence occurs together with the loculicidal dehiscence at the ventral and dorsal parts of each mericarp to release the seeds.

\section{Secretory structures}

Two types of secretory structures are present at the E. milii pericarp: idioblasts (Figs. 2e, 3a,c) and laticifers (Fig. 2c,e), the two of them at the nonlignified part of the mesocarp.

The idioblasts are already present in the pistillate flower (Fig. 2a), but at a small amount. In the fruit, all of the exocarp cells, except for the guard cells, present secretory substances inside (Fig. 2e, 4a). Secretory cells differentiate at the mesocarp, forming the hypodermis, which presents one to two cell layers adjacent to the exocarp (Fig. 2e). Besides, idioblasts abound at the septa (Fig. 3a-c), at the region where the division of the mericarps occurs. The secretion from these secretory structures occupies almost all of the cell lumen (Fig. 3a,c) and is stained in green by the toluidine blue.

The laticifers are apparently the same as those at the ovary wall, and no neoformation of these structures was observed during the fruit development. They are located at a region where very little cell proliferation occurs (Fig. 2c,e) and they are little branched.

\section{Seed}

On the mature seed, a protuberance is observed next to the hilum (Fig. 1e), composed of palisade exotegmen cells, which are lignified and longer then at the rest of the seed, and by the proliferation of the other cell layers of the tegmen (Fig. 4e). This proliferation of the inner tissues constitutes a pseudocaruncle (Fig. 1e), originated at the endostome region and with no storage of substances (Fig. 4e). The histochemical tests have not detected reserve substances in this tissue.

On the other hand, the uniseriate exotesta is secretory, and starts its glandular activity (Fig. 5a) after the lignification of the pericarp tissues, just before the dehiscence. All of the exotesta cells are secretory (Fig. 5b-h), including those at the pseudocaruncle region next to the hilum (Fig. 5d), and have different shapes along the irregular surface of the seed (Figs. 1e,f, 5b-h). The cells at the higher regions are globose (Figs. 1f, 5a-h), while those at the cavities are elongated (Figs. 1f, 5c, $\mathrm{f}-\mathrm{g}$ ). The cell walls are thin (Fig. 5a-c), stain in magenta by the Toluidine Blue and are coated by a thin cuticle (Fig. 5c). At the beginning of the secretory activity, the cells present a dense aspect cytoplasm and the nucleus at a central position (Fig. 5a). The secretion produced by these cells is released by the cytoplasm, but does not cross the cell wall, and accumulates at the space between the protoplast and the wall, referred to as periprotoplastic space for the first time in this work. During the secretory activity, the protoplast contracts, and at the end, the secretion occupies all the cell lumen; then, the protoplast disintegrates almost completely (Figs. 5b-c,e-g). The secretion, which in vivo is white and coats 


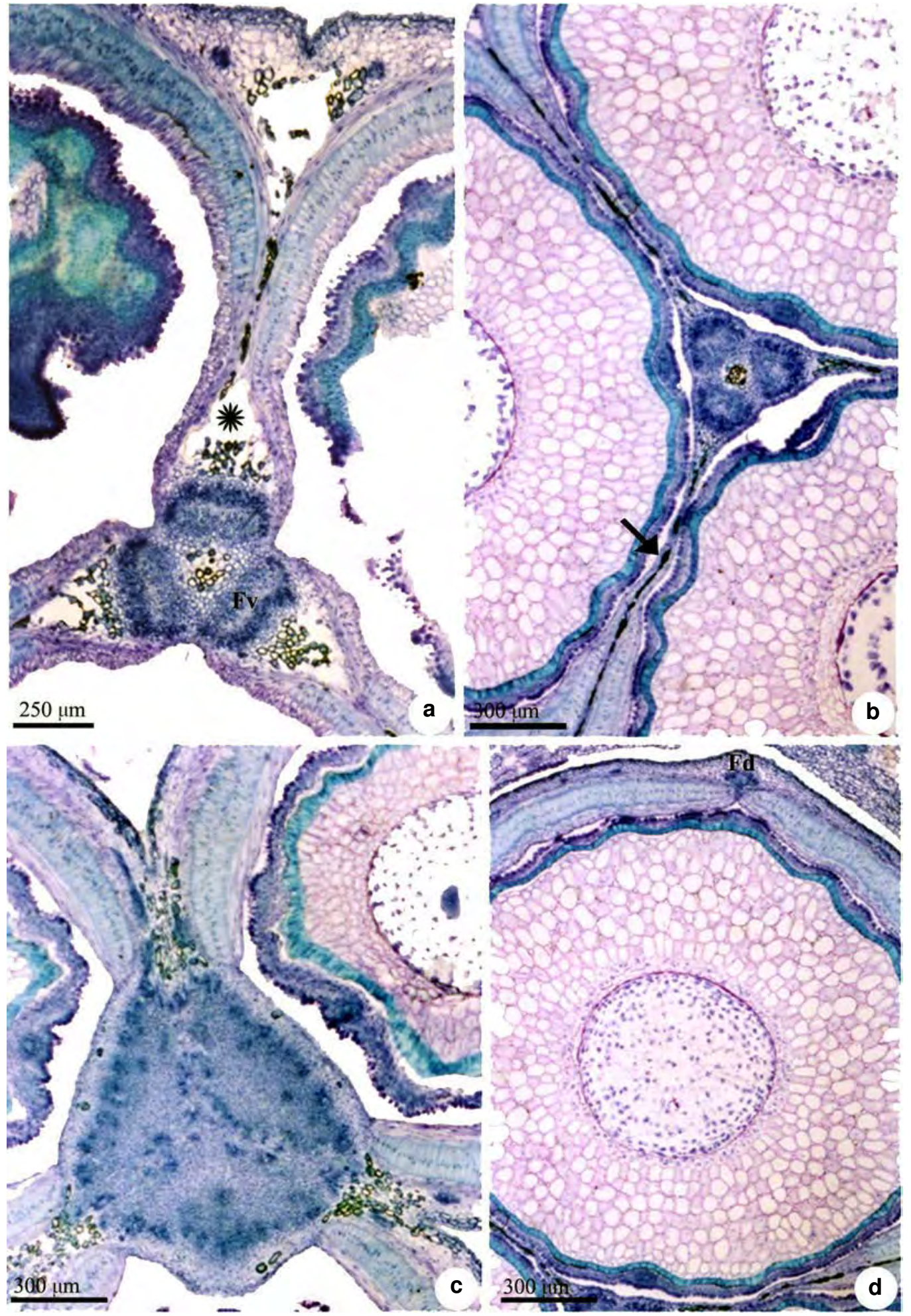

Figure 3 - Immature fruit of Euphorbia milii Desmoul. Transversal sections of different parts of the fruit-a. basal part. Note regions with cell degeneration (asterisk) near the central columella, where vascular strands (Fv) can be seen; b. medium part. Note thin septa (arrow) with idioblasts; c. apical part; d. general view of mericarp. Note abrupt end of the zones with differentiated tissues near the dorsal strand $(\mathrm{Fd})$. 

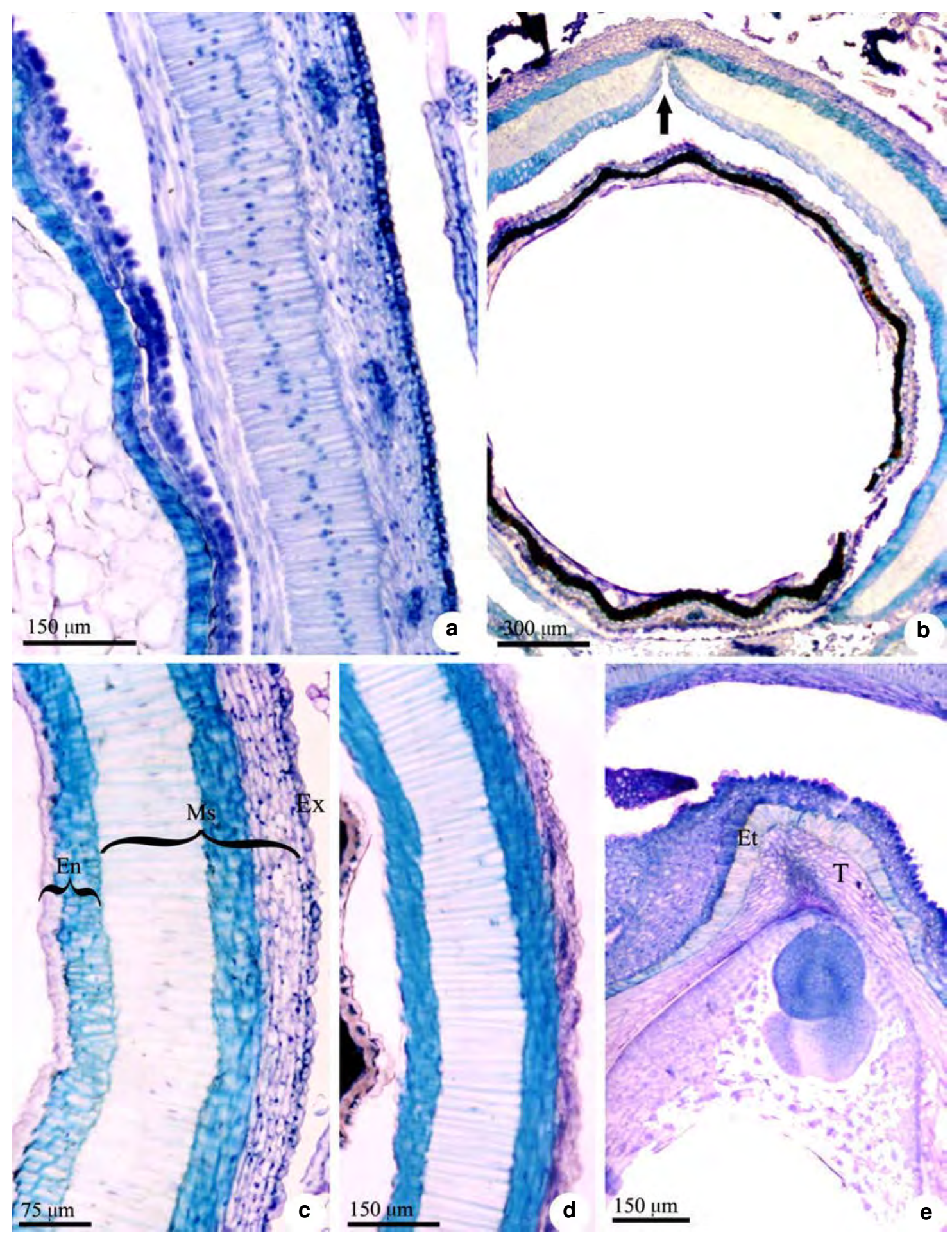

Figure 4 - Fruit and seed of Euphorbia milii Desmoul. - a,e. longitudinal sections; b-d. transversal sections - a. immature fruit; b. mericarp in pre-dehiscence, displaying the absence of pericarp lignified layers near the dorsal strand (arrow); c. pericarp with the three lignified zones differentiated before desiccation $(\mathrm{En}=$ endocarp; $\mathrm{Ex}=$ exocarp; $\mathrm{Ms}=\mathrm{mesocarp})$; d. dry pericarp. Note the shrinking of the non lignified tissues; e. apical part of the mature seed. Note pseudocaruncle formed by tegmen tissues $(\mathrm{T})$ with more elongated exotegmen cells $(\mathrm{Et})$. 
the mature seed, is exclusively mucilaginous, and is responsive to tannic acid and ferric chloride (Fig. 5d-e), ruthenium red (Fig. 5f), alcian blue (Fig. 5g) and PAS (Fig. 5h). Lipids and phenolic compounds have tested negative.

\section{Discussion}

Most of the Euphorbiaceae fruits are schizocarps with three mericarps and explosive dehiscence, but there are also fleshy or indehiscent fruits (Webster 1994; Esser 2003). Some species present dry fruits with colored and fleshy seeds, such as the Sapium Jacq., and others present red coloration, which may indicate seed dispersal by birds, and also the presence of dry fruits with thorns, which may indicate the occurrence of epizoochory, such as Mallotus Lour. and Chaetocarpus Schreb. Despite the morphological diversity of the fruits found in species of this family, few genera vary according to the type of fruit (Esser 2003). Some authors consider the predominant Euphorbiaceae fruit type as a capsule (Sablon 1884; Berg 1975). In this case, it is considered a tricocca capsule, as described for Manihot caerulescens Pohl and M. tripartita Müll. Arg. (Oliveira \& Oliveira 2009) and Euphorbia (Subils 1977; Jimenez \& Morales 1978), except for a few cases, such as Mercurialis annиa L., whose fruit is a capsule with two lobes separated by a septum (Lisci \& Pacini 1997).

Euphorbia milii presents a schizocarp with three mericarps having a glabrous, irregular surface, and it is about $5 \mathrm{~mm}$ in length and width. In other Euphorbia species, the fruits vary from subcircular to trilobate in frontal view, having an irregular surface, with indumentum or glabrous, and dimensions varying between $2.38 \times 2.66 \mathrm{~mm}$ and $4.7 \times 5.19 \mathrm{~mm}$ among the species and even in the same population (Subils 1977; Simon et al. 1992). So, the sampled E. milii fruits, although small in size, are among the largest ones when compared to other species of the genus.

The modifications on the pistil wall for fruit formation here observed are similar in all species of Euphorbia. The outer epidermis and the external region of the ground tissue, which contains the vascular strands and laticifers, do not present any remarkable difference, as opposed to inner region, which forms three sclerified zones on the mature fruit (Lavialle \& Delacroix 1922a,b,c; Jimenez \& Morales 1978). This same fruit structure is also found in dry fruits from other Euphorbiaceae genera, such as Hevea (Muzik 1954), Manihot (Toledo 1963;
Oliveira \& Oliveira 2009) and Mercurialis (Sablon 1884; Lisci \& Pacini 1997).

The first significant changes during the development of the E. milii fruit take place at the ovary inner epidermis, and originate the endocarp with three to four layers of lignified oblique cells, except for the innermost layer, which does not lignify. In several Euphorbia species, the ovary inner epidermis also multiplies, forming a sclerified zone with one to four fiber layers $45^{\circ}$ tilted in relation to the fruit axis; yet, the cells coating the locule elongate, forming trichomes that vary in structure and size (Lavialle \& Delacroix 1922a, b, c; Jimenez $\&$ Morales 1978).

In E. milii, the lignified part of the mesocarp, in its inner region, consists of a layer of palisade cells and about four layers of oblique cells. Likewise, in other species of the genus, the layer of parenchymatous subepidermal cells elongates only radially, forming a palisade sclerified zone, and the last sclerified zone is also formed by three to four elongate fiber layers, $45^{\circ}$ tilted perpendicular to the inner tilted fibers. This last zone has no important variations amongst the species of the genus, unlike the others, which present varying characteristics according to the species (Lavialle \& Delacroix 1922a,b,c). According to Jimenez \& Morales (1978), the E. atropurpurea Brouss. palisade zone is consisted of two cell layers, unlike the other species of the genus.

In the E. milii pericarp, as well as in the other Euphorbia species, the vascular strands distribution is the same as in the ovary, with variations only in the degree of development of the elements; furthermore, neither the outer parenchymatous zone to the strands nor the exocarp show significant variation during the fruit development (Lavialle \& Delacroix 1922a,b,c; Jimenez \& Morales 1978).

This constitution of the pericarp in the Euphorbia species divided in three sclerified zones, two of them consisted of obliquely elongated fibers and perpendicular to each other with a intermediate palisade zone (Lavialle \& Delacroix 1922a,b,c) is very common in the Euphorbiaceae species that have dry fruits, and was described for Mercurialis species (Sablon 1884; Lisci \& Pacini 1997) and Manihot (Toledo 1963; Oliveira \& Oliveira 2009).

During the development of the E. milii fruit, a lysis of the septa parenchymatous cells occurs, dividing the fruit into three mericarps, which one with having a seed. After reaching its maximum dimensions, the fruit starts a desiccation process 

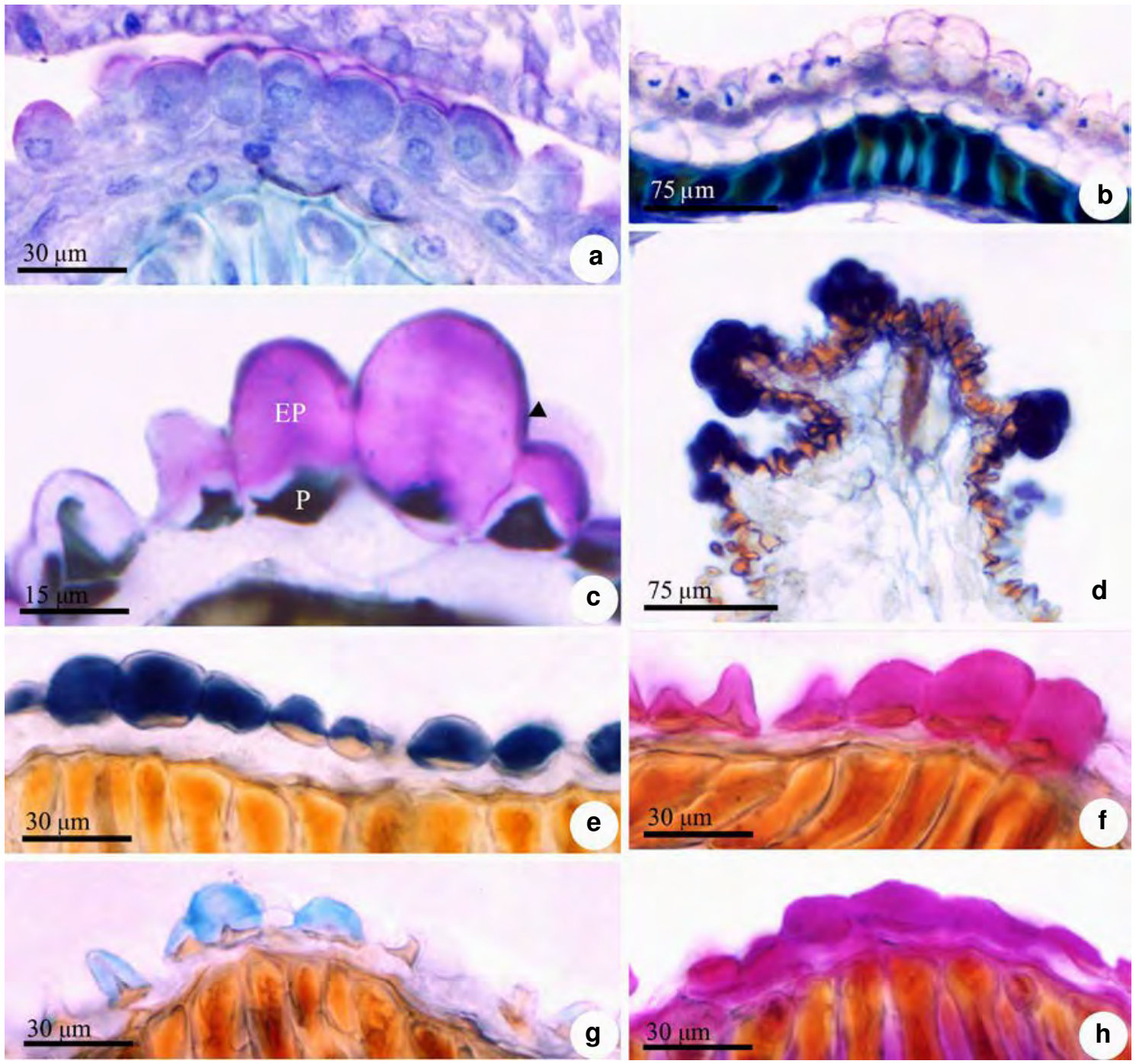

Figure 5 - Structure and histochemistry of the secretory exotesta of Euphorbia milii Desmoul. - a. beginning of secretory activity of the exotesta cells; b-c. secretory phase of the exotesta cells. Section stained with Toluidine Blue and Sudan black B; c. note the retraction of the protoplast $(\mathrm{P})$ and the wall stained in magenta, in the region of the periprotoplastic space (EP), coated by a thin cuticle stained in black (arrow head); d-e. tannic acid and ferric chloride; f. ruthenium red; g. alcian blue; h. PAS reaction.

due to increase in ambient temperature, causing a growing mechanical stress at the lignified tissues which, due to the different cell elongation orientations of each of the three zones, causes the explosive dehiscence of the mericarps along the dorsal strand (loculicidal dehiscence), throwing the seed distant from the mother plant. Each one of the mericarps halves (valves) acquires a helical aspect during the dehiscence, due to the contractions in opposed directions at the sclerified zones, aiding the projection of the seeds.
As observed in this study, nine break lines were observed in fruits of other Euphorbia species: three passing through the carpels plane of symmetry (loculicidal), three in the sutural plane until the central columella (septicidal), and three separating the mericarps from the central columella (septifragal), originating six valves, which correspond to the halves of each mericarp, and acquire a helical aspect when separated (Lavialle \& Delacroix 1922c; Jimenez \& Morales 1978). The central columella is also persistent in E. atropurpurea 
(Jimenez \& Morales 1978). The loculicidal dehiscence caused by the desiccation provoked by temperature and the different degrees of contraction between the layers of lignified cells, of different orientations, was observed in dry fruits of Euphorbiaceae since the first studies on fruits anatomy for species of this family (Sablon 1884) and also described for Beyeria viscosa Miq., Manihot utilissima Pohl, Manihot tripartita e Mercurialis аппиа (Toledo 1963; Berg 1975; Lisci \& Pacini 1997; Oliveira \& Oliveira 2009).

The secretory structures found in the E. milii fruit are idioblasts and laticifers. There are no anatomical records of secretory hypodermis in fruits of other species of the family, and only the presence of laticifers was reported in some species (Lavialle \& Delacroix 1922a,b,c; Muzik 1954; Toledo 1963; Jimenez \& Morales 1978; Oliveira \& Oliveira 2009), and phenolic idioblasts only in Manihot caerulescens e M. tripartita (Oliveira \& Oliveira 2009). All of the exocarp cells, except for the guard cells, accumulate substances during the development of the fruit, which gives a reddish color to the pericarp before its desiccation. Both the hypodermal cells and the several idioblasts present in the septa secrete phenolic compounds which stain green by the toluidine blue. At least part of the phenolic compounds found in some septa cells seem to be related to the death of those cells. Secretory cells of phenolic compounds were also found aplenty underlying the exocarp and in the septa of Manihot species (Oliveira \& Oliveira 2009).

The laticifers are present near the vascular tissue and in the parenchymatous mesocarp (between the vascular strands and the exocarp). Apparently, the laticifers present in the pericarp are the same which were present at the ovary. Although there can be a growth of the laticifers following the fruit growth, its neoformation was not observed. The Euphorbia species, in general, have laticifers in the parenchymatous region of the pericarp (Lavialle \& Delacroix 1922a,b,c), but in $E$. atropurpurea, they occur in all of the ground tissue and in the phloem (Jimenez \& Morales 1978); in Manihot utilissima, they are associated mainly with the phloem (Toledo 1963), but may be formed and scattered through the mesocarp in other species, such as $M$. caerulescens, M. tripartita (Oliveira \& Oliveira 2009) and Hevea brasiliensis (Willd. ex A.Juss.) Müll.Arg. (Muzik 1954), where most of them are formed after the capsule raises considerably in size. The production of phenolic compounds and latex by E. milii fruits is related to defense against frugivory during the development until the fruits become mature and release its seeds.

The dispersion of E. milii seeds is autochorous, through the explosive dehiscence of the pericarp. The autochory is primitive in Euphorbiaceae, and is present in many genera. However, species having their seed dispersal by ants and fleshy fruits dispersed by birds are also frequent (Berg 1975; Webster 1994; Lisci \& Pacini 1997; Esser 2003; Narbona et al. 2005). The distance reached with explosive autochory is small, and in many species it is increased secondarily via myrmecochory. The Euphorbia species, in most cases, have seeds with elaiosomes which attract ants and promotes a secondary dispersion (Berg 1975; Narbona et al. 2005). This type of dispersion is a Diplochory known as "euphorbia-like", and the differences between the distances reached by autochory and, posteriorly, by myrmecochory, depend on the seed mass and elaiosome retention (Berg 1975; Esser 2003; Narbona et al.2005). This type of dispersion was also recorded in Beyeria e Mercurialis (Berg 1975).

Morphologically, the elaiosome can be a caruncle, an aril or a chalazal protrusion (Boesewinkel $\&$ Bouman 1984). This appendix contains reserves, usually lipids, but proteins and starch were also recorded (Liszt et al. 1981; Lisci et al. 1996; Lisci \& Pacini 1997). Several functions are attributed to the elaiosomes, such as dehydration, hydration, dormancy, and water storage (Lisci et al. 1996), and in Euphorbiaceae, they are usually attached to a caruncle (Berg 1975), which has been mentioned for several genera (Singh 1969; Toledo 1963; Liszt et al. 1981; Lisci et al. 1996; Tokuoka \& Tobe 2002; Narbona et al. 2005). According to Tokuoka \& Tobe (2002), only 10 Acalyphoideae genera have caruncle seeds, and in Crotonoideae and Euphorbioideae, the seeds present caruncle in most genera, but its presence can vary in a same tribe or in different species of a same genus; this occurs in Euphorbia (Simon et al. 1992; Webster 1994), where its presence was considered primitive (Simon et al. 1992). According to Subils (1977) and Jordan \& Hayden (1992), the presence or absence of the caruncle in Euphorbia species has a taxonomic value.

According to Bor \& Bouman (1974), the mature seed of $E$. milii has an inconspicuous caruncle on the ventral micropylar side; however, this seed protuberance is due to a proliferation of tegmen tissues at the endostome region, as also observed by the referred authors, and therefore cannot be 
considered as a caruncle, since the caruncle results from the ovule outer integument at the micropyle region (Kapil et al.1980). For this reason, such protuberance is named pseudocaruncle in this study. In addition, the cells in this pseudocaruncle do not accumulate reserve substances or allow secondary dispersion by ants.

On the other hand, the seeds of $E$. milii have a secretory exotesta. According to Werker (1997), this layer can be continuous or discontinuous, and Bor \& Bouman (1974) described the exotesta secretory cells of $E$. milii as restricted to the high portions of the seed coat, and the others as non-secretory papillose cells; however, in this study, it was observed that all of the exotesta cells are secretory, although having different shapes. The presence of secretory exotesta has been related for other Euphorbia species (including Chamaesyce) (Carlquist 1966; Jordan et al. 1985; Jordan \& Hayden 1992).

The exotesta cells start its secretory activity just before the fruit dehiscence. In general, the production of exudate begins when the secretory cells are completely expanded, although the seed may not have reached its final size (Werker 1997), but in Euphorbia species (= Chamaesyce), as observed in this study, the secretory activity begins later during the seed coat ontogeny (Jordan \& Hayden 1992). The walls of the exotesta cells in $E$. milii are colored in magenta, revealing a high concentration of pectins, and are coated by a thin cuticle. The protoplast degenerates during the secretory stage, and is extremely reduced in mature seeds; in this stage, the exudate, which is accumulated in a space between the protoplast and the wall, occupies almost all of the cell lumen. In this study, the term periplasmic was updated based on the current concept of protoplast, and is therefore called periprotoplastic space.

According to previous records, including the one made by Bor \& Bouman (1974) for E. milii, the secretion of Euphorbia seeds is mucilaginous (Carlquist 1966; Subils 1977; Jordan et al. 1985; Jordan \& Hayden 1992); however, these reports are based solely on the secretory aspect when the seed is placed in water. Based on histochemical tests accomplished in the present study for detection of different classes of chemicals, it was confirmed for the first time that the white secretion of the E. milii exotesta which covers the mature seed is exclusively mucilaginous. The only previous record based on the secretion composition was made by Jordan et al. (1985), describing the exudate of the E. supina Raf. seeds as having a polysaccharide origin, probably mucilaginous.

Mucilage secretory cells are present in seeds of species in several families and are normally epidermal, but in some genera there are also subepidermal cells (Werker 1997), and its development is similar to the one observed in $E$. milii. The mucilage normally fills almost all of the cell lumen, and is stored between the wall and the protoplast, which becomes compressed at the cell basis (Hyde 1970; Werker 1997). In mature seeds of Plantago ovata Forsk., the secretory cells of the seed coat have thin walls that break when in contact with water, and the mucilage in each cell forms a column which is three times bigger then the original cell (Hyde 1970).

Different functions have been attributed to the mucilage produced by the seeds of Euphorbia species, such as adherence to the soil surface when moistened, with the benefit of not having the seed carried by the wind or rain to adverse places; reduction of the diaspore specific weight in the water; prevention from desiccation; epizoochory by adherence to animals (Carlquist 1966; Fahn 1990; Werker 1997); but its main function, as it occurs in E. milii and has already been related by Jordan et al. (1985) and Jordan \& Hayden (1992), is to aid the diffusion of the soil water to the seed, due to the mucilage hygroscopic property, easing its soaking.

\section{Acknowledgments}

The authors thank the "Programa de Pósgradução em Biologia Vegetal da Universidade Estadual de Campinas", whereby this work was conducted.

\section{References}

Berg, R.Y. 1975. Myrmecochorous plants in Australia and their dispersal by ants. Australian Journal of Botany 23: 475-508.

Boesewinkel, F.D. \& Bouman, F. 1984. The seed: structure. In: Johri, B.M. Embryology of angiosperms. Springer, Berlin. Pp. 567-610.

Bor, J. \& Bouman, F. 1974. Development of ovule and integuments in Euphorbia milii and Codiaeum variegatum. Phytomorphology 24: 280-296.

Cain, A.J. 1947. The use of Nile Blue in the examination of lipids. Quarterly Journal of Microscopical Science 88: 383-392.

Carlquist, S. 1966. The biota of long-distance dispersal. III. Loss of dispersibility in the Hawaiian Flora. Brittonia 18: 310-335.

Esser, H. 2003. Fruit characters in Malesian Euphorbiaceae. Telopea 10: 169-177. 
Fahn, A. 1990. Plant anatomy. 4ed. Pergamon Press, Oxford. 588p.

Gabe, M. 1968. Techniques histologiques. Masson \& Cie, Paris. 1113p.

Ganter, P. \& Jollés, G. 1969, 1970. Histologie normale et pathologique. 2 vol. Gauthier-Villars, Paris. 1904p.

Gerlach, D. 1984. Botanische Mikrotechnik: eine Einführung. 3ed. Georg Thieme, Stuttgart. 311p.

Gerrits, P.O. 1991. The application of glycol methacrylate in histotechnology; some fundamental principles. Department of Anatomy and Embryology, State University Groningen, Groningen. 80p.

Gregory, M. \& Baas, P. 1989. A survey of mucilage cells in vegetative organs of the dicotyledons. Israel Journal of Botany 38: 125-174.

High, O.B. 1984. Lipid histochemistry. Oxford University Press, New York. 68p.

Hyde, B.B. 1970. Mucilage-producing cells in the seed coat of Plantago ovata: developmental fine structure. American Journal of Botany 57: 1197-1206.

Jimenez, M.S. \& Morales, D. 1978. Histología floral y desarrollo del fruto de Euphorbia atropurpurea Brouss. Vieraea 8: 131-143.

Johansen, D.A. 1940. Plant microtechnique. McGrawHill, New York. 523p.

Jordan, M.S. \& Hayden, W.J. 1992. A survey of mucilaginous testa in Chamaesyce. Collectanea Botanica 21: 79-89.

Jordan, L.S.; Jordan, J.L. \& Jordan, C.M. 1985. Changes induced by water on Euphorbia supina seed coat structures. American Journal of Botany 72: 1530-1536.

Kapil, R.N.; Bor, J. \& Bouman, F. 1980. Seed appendages in angiosperms. I. Introduction. Botanische Jahrbücher für Systematik 101: 555-573.

Lavialle, P. \& Delacroix, J. 1922a. La paroi du pistil et du fruit dans le genre Euphorbia. Comptes Rendus Hebdomadaires des Séances de l'Académie des Sciences 175: 179-181.

Lavialle, P. \& Delacroix, J. 1922b. Caractères de l'endocarpe dans le genre Euphorbia. Bulletin de la Société Botanique de France 69: 523-527.

Lavialle, P. \& Delacroix, J. 1922c. Caractères histologiques du péricarpe et déhiscence du fruit chez les Euphorbes. Bulletin de la Société Botanique de France 69: 585-590.

Lillie, R.D. 1965. Histopathologic technic and practical histochemistry. 3ed. McGraw-Hill, New York. 715p.

Lisci, M.; Bianchini, M. \& Pacini, E. 1996. Structure and function of the elaiosome in some angiosperm species. Flora 191: 131-141.

Lisci, M. \& Pacini, E. 1997. Fruit and seed structural characteristics and seed dispersal in Mercurialis annua L. (Euphorbiaceae). Acta Societatis Botanicorum Poloniae 66: 379-386.

Liszt, K.; Sárkány, S.; Kadej, J. \& Kovács, A. 1981. Light and electron microscopic observations in connection with the developing pistil and seedappendix (caruncle) of Ricinus communis L. Acta Societatis Botanicorum Poloniae 50: 345-348.

McManus, J.F.A. 1948. Histological and histochemical uses of periodic acid. Stain Technology 23: 99-108.

Muzik, T.J. 1954. Development of fruit, seed, embryo, and seedling of Hevea brasiliensis. American Journal of Botany 41:39-43.

Narbona, E.; Arista, M. \& Ortiz, P.L. 2005. Explosive seed dispersal in two perennial Mediterranean Euphorbia species (Euphorbiaceae). American Journal of Botany 92: 510-516.

O’Brien, T.P.; Feder, N. \& McCully, M.E. 1964. Polychromatic staining of plant cell walls by toluidine blue O. Protoplasma 59: 368-373.

Oliveira, J.H.G. \& Oliveira, D.M.T. 2009. Morfoanatomia e ontogênese do pericarpo de Manihot caerulescens Pohl e $M$. tripartita Müll.Arg. (Euphorbiaceae). Revista Brasileira de Botânica 32: 117-129.

Pearse, A.G.E. 1985. Histochemistry: theoretical and applied. 4ed. Vol. 2. C. Livingstone, Edinburgh. 624p.

Pizzolato, T.D. 1977. Staining of Tilia mucilages with Mayer's tannic acid- ferric chloride. Bulletin of the Torrey Botanical Club 104: 277-279.

Sablon, L. du 1884. Recherches sur la déhiscence des fruits a péricarpe sec. Annales des Sciences Naturelles. Botanique et Biologie Vegetale 18: 5-104.

Simon, J.; Molero, J. \& Blanché, C. 1992. Fruit and seed morphology of Euphorbia aggr. flavicoma. Taxonomic implications. Collectanea Botanica 21: 211-242.

Singh, R.P. 1969. Structure and development of seeds in Euphorbia helioscopia. Botanical Magazine Tokyo 82: 287-293.

Subils, R. 1977. Las especies de Euphorbia de la Republica Argentina. Kurtziana 10: 83-248.

Tokuoka, T. \& Tobe, H. 2002. Ovules and seeds in Euphorbioideae (Euphorbiaceae): structure and systematic implications. Journal of Plant Research 115: 361-374.

Toledo, A.P. 1963. Anatomia e desenvolvimento ontogenético do fruto e da semente de mandioca. Bragantia 22: 71-76.

Webster, G.L. 1994. Classification of the Euphorbiaceae. Annals of the Missouri Botanical Garden 81: 3-32.

Werker, E. 1997. Seed anatomy (Handbuch der Pflanzenanatomie; Bd. 10, Teil 3). Gebrüder Borntraeger, Berlin. 424p. 